\title{
Insurgency in Southern Thailand: A Quest for Identity
}

\author{
Till Maximilian Möller*
}

\begin{abstract}
The violence caused by the protracted conflict between a Malay-Muslim insurgency and the Thai state in the country's Deep South has re-escalated in 2004 and is producing alarming numbers of victims ever since. The conflict is highly complex and driven by the interplay of a multitude of factors. Despite having remained localized and not spilling over into neighbouring regions or Bangkok, in the post-9/11-era attempts have been made to link the insurgency to groups advocating global jihad. This article's goal is to avoid such simplifying mono-causal explanation attempts and help understand the conflict's root causes by looking at the roles of history, identity politics and the pre-cursors of the present insurgency.
\end{abstract}

Keywords: Südthailand; Ethno-religiöse Konflikte, Terrorismus, Widerstandsbewegungen Southern Thailand, ethnic-religious conflicts, terrorism, insurgency / resistance movements

\section{Assessing the Conflict Region and Parties}

$\mathrm{T}$ The conflict in four of Thailand's southernmost provinces in the region bordering Malaysia has dramatically affected the lives of the local population. Daily incidents of shootings and bombings have led the total death toll to climb to over 4,100 since the re-escalation of violence in 2004, with an additional 6,500 people injured (Jitpiromsri, 2010). Unlike previous phases of rebellion and insurgent activity in the region, this new wave of violence has remained enigmatic in many respects, especially regarding the question of who is masterminding the insurgency. Despite the fact that many researchers and institutions like the International Crisis Group (ICG) point to Barisan Revolusi Nasional-Coordinate (BRN-C) as being the most important insurgent group active today, no official statements or declarations by this group that claim responsibility for specific attacks have been put forward. While some insights into the recruitment process and the modus operandi of the insurgency have been gained, its exact structure, goals and leaders remain unknown (International Crisis Group, 2009). ${ }^{1}$

The region affected by the turmoil is comprised of the Thai provinces Pattani, Narathiwat and Yala, as well as five districts of neighbouring Songkhla (Chana, Na Thawi, Sabayoi, Sabao and Thepa). This area, covering about $18,350 \mathrm{~km}^{2}$, is home to around three million people, which equals less than 5 percent of Thailand's total population, and accounts for only about 3 percent of the country's total land mass. However, over 65 percent of Thailand's Muslim population is concentrated in the three provinces of Narathiwat, Pattani and Yala alone (Melvin, 2007:5).

Therefore, Islam is the majority religion in the region, with only roughly 20 percent of the population being non-Muslim (McCargo \& Jitpiromsri, 2008:411), which stands in sharp contrast to the fact that about 94 percent of all Thai citizens adhere to Buddhism (Yusuf, 2007:4). This asymmetric religious

* Till Möller is project manager at Berghof Conflict Research, Berlin. He works on conflict transformation projects in Southeast Asia.

1 For an overview on the insurgency see Zachary Abuza's "Conspiracy of Silence” (2009), the fourth chapter of Duncan McCargo's “Tearing Apart the Land", entitled "Militants" (2008:135-181), and the International Crisis Group's report "Southern Thailand: Insurgency, not Jihad" (2005). cleavage is mirrored by an ethnic divide, as the Muslims of the conflict region are ethnically Malay. ${ }^{2}$ The two distinct categories of ethnic and religious identity are viewed as inseparable and interchangeable by the majority of the local population, as "for the Malays of Patani, 'Malayness' and Islam are virtually indistinguishable" (Christie, 1998:182). This also reflects in terms of language. The phrase used by Malay-Muslims to describe the process of conversion to Islam is "masuk Melayu", literally meaning "entering ‘Malayness"” (Yusuf, 2007:9).

The ethno-religious differences between Malay-Muslims and Thai-Buddhists are further broadened by a language gap. Thai, the national language, is not spoken by the majority of the population in the conflict region, as most Malay-Muslims only speak a local dialect of the Malaysian language (Bahasa Melayu). When it is written, this is either done by using an Arabic script called Jawi - alluding to the felt closeness of the region to the Arabian Peninsula as the cradle of Islam - or in the Roman alphabet (locally referred to as Rumi). Due to the fact that the Thai state is extremely reluctant towards allowing Malay (and Jawi) to be introduced as an official second language in the Deep South, interactions with the state remain a challenge for southern Thailand's Malay-Muslims as well as contributing to difficulties in the job market. Even Thai politicians with a track record of being moderates regarding the southern conflict have repeatedly taken a hard stance on the language issue. Prem Tinsulanond, who during his reign as prime-minister in the 1980s contributed immensely to bringing temporary peace to the region, said in 2006 as a reaction to the National Reconciliation Commission's advice to introduce Malay as a complimentary second official language in the southern region: "We cannot accept that [proposal] as we are Thai. The country is Thai and the language is Thai.... We have to be proud to be

2 Despite the fact that virtually all literature on southern Thailand's Muslims refers to them as "Malays", the notion that the Muslims of Pattani, Narathiwat and Yala can be classified as "Malays" is being increasingly questioned by some scholars. Their argument is that it remains a matter of debate what criteria is applied in order to classify a group as being Malay. Anthony Milner (2010) argues in favor of using the term 'Malayness' instead, referring to a cluster of cultural, linguistic and ethnic traits and practices. With regard to the Muslims of Thailand's Deep South, Milner points out that historically the Sultans of Patani were explicit in not referring to themselves as "Malays" (Milner, 2010:75). 
Thai and have the Thai language as the sole national language." (Melvin, 2007:37)

\subsection{The Historical Dimension}

Understanding the often overlooked historical dimension of this conflict is crucial as it not only holds answers regarding the motivation of the insurgents, but also explains why the conflict is this protracted and localized. Despite the Zeitgeist's influence on the ever-changing insurgency, it is the underlying historical narrative of resistance against occupation and oppression that fuels the fire in the Deep South.

The region affected by the conflict today is virtually identical with the space previously occupied by the Muslim Sultanate of Patani. ${ }^{3}$ This Sultanate existed from the middle of the 15 th century, when according to legend the Raja of Patani, Raja Indra, converted to Islam and took the name Mahmud Shah after having been healed by a Sheikh (Syukri, 1985:16/17), and it lasted until its incorporation into the Siamese state in the early 20th century. After the first Portuguese ship had landed in Patani in 1516, the Sultanate blossomed and its economic as well as military power grew steadily, mostly due to trade with Europeans and the introduction of cannons (Grabowsky, 1995:196/97). After the last male Sultan had passed away, four queens subsequently ruled the Sultanate of Patani - a phase that is considered its heyday and often referred to as its "glorious past" by today's Malay-Muslims.

The Sultanate's interactions with its big northern neighbour, Siam, had been problematic almost from the start. Though generally considered a tributary state to Siam, the Sultanate of Patani was autonomous and the Sultan's rule over his subjects remained unquestioned. The system of tribute that was in place was no more than a symbolic gesture by smaller kingdoms that demonstrated respect towards kingdoms of greater power. Every three years, the Sultanate of Patani sent bunga emas dan perak, "flowers" crafted from gold and silver, to the Siamese capital in order to show respect to the Siamese king. Yet, at the same time Siam was paying tribute to its northern neighbour China a clear indication that this symbolic act of paying tribute should not be interpreted as an automatic loss of sovereignty. This Mandala system of power regulated the interaction of Patani and Siam as well as that of many other Southeast Asian kingdoms. At its centre were a king or Sultan and the further one came to the periphery, the more his power diminished. Precise state lines were unknown before the advent of nationstates. This rather vague system, which also allowed for overlap and areas of contention, has been compared to the interplay of the light of candles in a dark room, each brightest in the centre and shining less brightly the further one moved away (Puaksom, 2008).

3 This also explains, at least in part, why the conflict has not spilled over into the neighbouring province of Satun as well as the other unaffected districts of Songkhla province, which also have a majority-Muslim population but were not part of the Sultanate. There are, of course, also other factors that come into play, such as the geographical location of Satun, which unlike the other provinces lies on the Andaman Sea rather than the Gulf of Thailand and the fact that most people in Satun speak the southern dialect of Thai rather than Malay, which has only remained popular among the older generation.
In 1563, when Siam was under siege from Burmese troops, the Sultan of Patani, who had been treated condescendingly by the Siamese king during a previous visit, had launched an attack on the Siamese capital of Ayutthaya. Despite the military success of the operation, the Sultan ordered his troops to return to Patani and left the town to the Burmese. From this point on, Siam not only had an economic interest in subjugating the prosperous Muslim Sultanate, but in addition wanted to seek revenge for this humiliating attack by what it considered a tributary state. Several attempts at conquering Patani - in 1603, 1632 and again in 1638 - failed. It was only in 1785, when Rama I, founder of the Chakri dynasty, managed to subjugate the Sultanate. From this point on, the Sultanate of Patani was beyond a mere tributary status and was effectively dominated by Siam. Following a number of reforms under Rama V (King Chulalongkorn) that had already split up the Sultanate into various districts, which were administered directly from Bangkok in order to shift power away from the Sultan and towards the Siamese king, the Sultanate of Patani was annexed by Siam in 1902. Seven years later it formally ceased to exist, when the area was officially recognized as part of Siamese state territory through the AngloSiamese Treaty of 1909.

\subsection{Identity Politics}

Beyond the scope of history, the conflict in Patani ${ }^{4}$ can also be understood as a struggle by the Malay-Muslims for the right to a distinct identity. In addition to the ethno-religious divide and the language barrier that are separating Malay-Muslims and Thai-Buddhists in Patani, the problematic concept of what it means to be a "good" Thai citizen has contributed to cementing the gap between the two groups.

Thai identity is formed around three central motives: the nation, religion (meaning Buddhism), and the king (Wang, 2005:27). Honouring these three concepts is viewed as equal to being a good Thai citizen. Yet, it should be evident that for the Malay-Muslims of Patani this identity concept, which is formulated in an exclusive, not inclusive way, fails to provide aspects that are easily accessible to them. Their nation was annexed; their religion is Islam; and the king, though he might get respected for his personality and general demeanour, is heir to the throne that subjugated the former Sultanate and took away its freedom. Vice versa from a Thai perspective the MalayMuslims, due to their refusal to give up their distinct identity, by definition cannot be good citizens of the state. This reflects in the term used by Thais to refer to the Malay-Muslims of the Deep South: khaek. This term, literally meaning "guest", but also carrying the connotation of meaning "stranger", exemplifies how alien many Thais perceive the Malay-Muslims to be (Jory, 2007:4-6).

4 From this point on the conflict region will be referred to as „Patani“, mirroring the fact that for many Malay-Muslims (and certainly to the insurgents) the former Sultanate of Patani, which encompassed the territory of the modern Thai provinces of Pattani (spelled with two "t"), Narathiwat and Yala as well as the aforementioned five districts of Songkhla province and therefore is identical with today's conflict region, is the imagined nation to which they feel a sense of belonging. 
To say that the Siamese/Thai state would not have tried to solve this problem would be untrue. Yet, never was its policy to change its own position through broadening its concept of citizenship in order to make it more accessible to the MalayMuslims and other minorities, but rather to force these groups to assimilate. The height of this process of forced assimilation attempts was reached under ultra-nationalist prime-minister Phibun Songkhram's first reign from 1938-44, when he forbade Malay-Muslims from wearing Sarongs, imposed Buddhist practices on them, and outlawed the use of Malay in all government offices through his "Cultural Mandates" (in Thai: ratthaniyom) (Farouk, 1987; Syukri, 1985). The process of creating a state-orchestrated Thai identity was constructed through a pattern of "othering" in an attempt to forge a new unity by pointing out that which was deemed to be "un-Thai" (Reynolds, 2005; 2006; Samudavanija, 2002). Another issue of great concern to the Malay-Muslim community was a staterun migration program that encouraged Thais, mostly from the north of the country, to settle in ready-built self-sufficient villages in the south (Walker, 2005:85). The more force the Thai state - whose name had been changed by Phibun in 1939 from Siam to Thailand in order to highlight the ethnic primacy of the Thai people and the linguistic primacy of Central Thai as the country's only official language - applied in order to force the people of the Deep South to integrate, the less willing they were to comply. In this sense the policies proved extremely counterproductive. As Joseph C. Liow and Don Pathan put it with reference to renowned Thai-studies scholar Charles F. Keyes:

"Among the insurgent community in southern Thailand the brand of nationalism that is being articulated with reference to ethnic Malay and Islamic dialectics has been a reaction to not only the centrality of ethnic Thai referents and the Buddhist religion in Thai national identity, but the perception that these norms and values are being forced upon them. Commenting on this disjuncture, Charles Keyes has noted that 'one of the underlying factors behind the virtual exclusion of ... Muslims from national politics is the equation of Buddhism with the national religion'. In many respects, it is this pattern of 'othering' emanating out of the political centre in Bangkok that has fostered suspicions among its Malay minority communities and fanned the flames of resistance over the years." (Liow and Pathan, 2010:47) $)^{5}$

One of the cornerstones in preserving a distinct Malay-Muslim identity in Patani have been the traditional Islamic schools, called pondoks. The Thai state made repeated attempts at regulating and shutting down these traditional pondoks, as they were seen as competing with the state-run schools, which in turn were perceived as centres for pro-Thai indoctrination and corruption of the faith by most Malay-Muslims.

This process proved counter-productive, as it led to two developments that only broadened the existing divide rather

5 While this article aims to help understanding the background of the insurgency in southern Thailand and therefore focuses on the MalayMuslim conflict party, to fully grasp the conflict's dynamic it is extremely helpful to look at the Buddhist dimension of this and similar conflicts, such as provided by Christopher Joll's "Religion and Conflict in Southern Thailand: Beyond Rounding Up the Usual Suspects" (2010) and Michael K. Jerryson's "Militarizing Buddhism: Violence in Southern Thailand" (2010). than drawing the Malay-Muslims in closer: (1) state-run schools, their teachers and military/police forces protecting these schools have become the insurgency's prime targets; and (2) the traditional pondoks came to be gradually replaced with private Islamic schools ${ }^{6}$, which despite being state-subsidized and teaching a double curriculum (meaning both an Islamic education as well as vocational subjects including the Thai language), have - often unknown to those that run them - apparently become a focal point for recruitment efforts by the insurgency's newest wave (International Crisis Group, 2009). They are staffed to a large percentage with religious teachers (ustadz) that have received their education abroad, mostly in Saudi-Arabia, Egypt and Sudan, as many Malay-Muslim parents had sent their children there due to the insufficient availability of traditional pondoks. While this has not led to an internationalization of the conflict as such, it did bring about a strong influx of reformist Islamic ideas that led to an increasing fragmentation of the previously fairly homogeneous Muslim community in the Deep South.

\subsubsection{The Fragmentation of the Islamic Community}

Reformist ideas of Salafi-brand Islam began to compete with the traditional and localized form of Islam that used to be dominant in Patani and contained more elements of Sufism and animism than this dogmatic form, which was rather new to the region. Furthermore, when the newest wave of insurgency started in 2004, the Zeitgeist of the post-9/11-era had already reached Patani and ushered in a new phase of re-focusing on religion just as it had happened in the late 1970s, when the Soviet's invasion in Afghanistan and the Iranian revolution had created a momentum that influenced insurgents groups in the entire Muslim world to re-focus on their religious identity.

This shift juxtaposed the localized "old school" Islam (or khana kau in Thai, kaum tua in Malay) with so-called "modernist" or "reformist" Islam, (dubbed khana mai in Thai and kaum muda in Malay). As tempting as it might be to therefore blame the reescalation of violence since 2004 on the influence of Salafism and speculate about links to "global jihad" fuelled by the same ideology, there are no indications that the insurgency in southern Thailand is branching out in order to co-operate with international or regional Salafist-Jihadist groups like Al-Qaeda and Jema'ah Islamiyah. In fact, the conflict has remained strictly confined to the region previously occupied by the Sultanate of Patani and not spilled over into the neighbouring provinces, let alone Bangkok. Also, it should be noted that particularly prominent Salafi-leaning Islamic scholars such as Ismail Lutfi have condemned the violence precisely out of religiously motivated reasoning as they view it as incompatible with Salafist teachings. As little is known about the insurgency due to its hyper-secrecy, it remains a matter of speculation what ideological motivation drives its higher echelons and whether traditionalists or reformists dominate. Most likely, the network

6 For an in-depth analysis of the role Islamic education plays in the conflict in southern Thailand, see Joseph Chinyong Liow's highly illuminating book "Islam, Education and Reform in Southern Thailand: Tradition and Transformation" (Liow, 2009). 
of insurgent groups is itself heterogeneous and comprised of groups with very different agendas and views on Islam.

The only two general changes in strategy by the insurgency, which seem to indicate a growing influence of Salafist ideas, are the increased targeting of fellow Muslims that are perceived as having "strayed from the path" or betrayed Islam, and the increasing number of beheadings. The process by which Salafis declare fellow Muslims to be non-believers (kafir) due to their actions is known as takfir and highly controversial. The number of assassinated Muslims in this conflict is astounding and has reached a point where Muslim victims actually comprise the majority of those killed. ${ }^{7}$ Frequently, leaflets are found that warn locals from co-operating in any way or form with the Thai state, as they would be viewed as traitors to Islam (munafiqh) and punished accordingly. This is an apparent push by the insurgents to strengthen group coherence and overcome the Muslim community's fragmentation by force. Whether the killing of fellow Muslims is actually motivated by takfir or simply by revenge on perceived traitors, yet unconnected to religious issues, remains an open question. The increasing number of beheadings, on the other hand, could be seen as an indication for Al-Qaeda-style jihad, as - like suicideattacks - they are one of the group's hallmarks. However, there is an important difference: While Al-Qaeda and similar global-jihadist groups perform these beheadings on victims that are alive, the beheadings in southern Thailand have all been performed post mortem. If anything, this is a crude and gruesome exemplification of the superficiality in which the AlQaeda-charged Zeitgeist has had an influence on this conflict. As many Malay-Muslims from Patani are quick to point out, another factor to consider when looking at the numbers of killed Muslims is the extra-judicial killings perpetrated by Thai security forces, which are being criticized time and again by international NGOs that deal with human rights issues (for an example see Human Rights Watch, 2007). Ordinary MalayMuslims are therefore targeted from both angles: the Thai military and police force on the one side and fanatic insurgents on the other.

\section{The Insurgent Groups}

\subsection{Earlier Waves of Insurgency}

Considering Patani's history of annexation, attempted deculturization of the population and its "guest-status" on Thailand's periphery, the ground for a resistance movement was prepared from the start. Haji Sulong, Patani's most prominent Islamic scholar of the first half of the twentieth century and arguably the first "modernist/reformist" in the region, argued for autonomy by presenting a seven-point-plan to a committee of the government of Pridi Phanomyong in April of 1947. It included provisions to have the provinces (including Satun) administrated by a local Malay-Muslim, argued for the acceptance of Malay/Jawi as an official local language and

7 This is only true for fatal attacks - the majority of those injured is comprised of Buddhist victims. All numbers and references to victims are taken from the report of the think-tank Deep South Watch: "Sixth Year of the Southern Fire" (Jitpiromsri, 2010). demanded the incorporation of Islamic law regarding matters of religion into the legal system on the local level (McCargo, 2008:60). The timing of this proposal proved fatal: Seven months after it had been handed in, Pridi was overthrown by a military coup and in April of 1948 ultra-nationalist hardliner Phibun took office for a second term as prime-minister.

Haji Sulong was arrested by the police and charges of treason were brought up against him, resulting in a sentence of three and a half years in jail (Aphornsuvan, 2004:40-48). The situation in the Deep South further escalated when a demonstration in the village of Dusun-Nyor spun out of control on 26-28 April 1948. A crowd of 1,000 Malay-Muslims got into clashes with the police and over 400 of them as well as 30 police officers died. This event led to the signing of a petition to the United Nations that was calling for Patani to secede from Thailand and join the newly formed Federation of Malaya. Allegedly, it was signed by more than half of the conflict province's adult population, yet proved unsuccessful in receiving the UN's backing (Walker, 2005:83).

The resistance movement spearheaded by Haji Sulong and others can hardly be seen as a full-blown insurgency. In fact, the only organisation fighting for the Malay-Muslims of southern Thailand in the late 1940s was Gabungan Melayu Patani Raya (GAMPAR), whose agenda was aimed at having Patani join the Federation of Malaya (Harish, 2006:6-8). When it became obvious that Patani would not be allowed to join the Federation of Malaya, the support for GAMPAR dwindled and other groups with a truly separatist agenda emerged. The first of these groups was Barisan Nasional Pembebesan Patani (BNPP). Conservative Islam played an important role in its ideology and it maintained a close cooperation with training grounds for Islamic teachers set up in Cairo and Mecca (Abuza, 2009:16/17). The BNPP seized to exist in the early 1980s and was succeeded by an offshoot called Barisan Bersatu Mujahideen Patani (BBMP) that soon renamed itself into Barisan Islam Pembebesan Patani (BIPP). However, both the BNPP as well as the BBMP/BIPP never managed to become mass movements let alone launch an effective insurgency.

Two organisations, which proved much more influential over the course of time, also emerged in the mid-1960s: the Patani United Liberation Organization (PULO) and Barisan Revolusi Nasional (BRN). While PULO was emphasizing the Islamic identity of the Malay-Muslims, it was still less conservative in religious terms than BNPP. Unlike these two groups, BRN wanted to implement a brand of "Islamic socialism" and was politically oriented rather than focussing on religion. The most successful and influential of the three groups over the course of the 1970s and 1980s was PULO. It occupied a middleground between conservative Islam and socialist ideology and promoted an ideology of "religion, race, homeland and humanitarianism" that attracted supporters both on the local as well as the international level (Melvin, 2007:16). The military strategy of these groups was that of traditional guerrilla warfare (Sugunnasil, 2007:113). They built up their guerrilla armies - in the case of PULO with some help from middle-eastern states and attacked representations of the Thai state. 
Table 1: Insurgent Groups in Southern Thailand

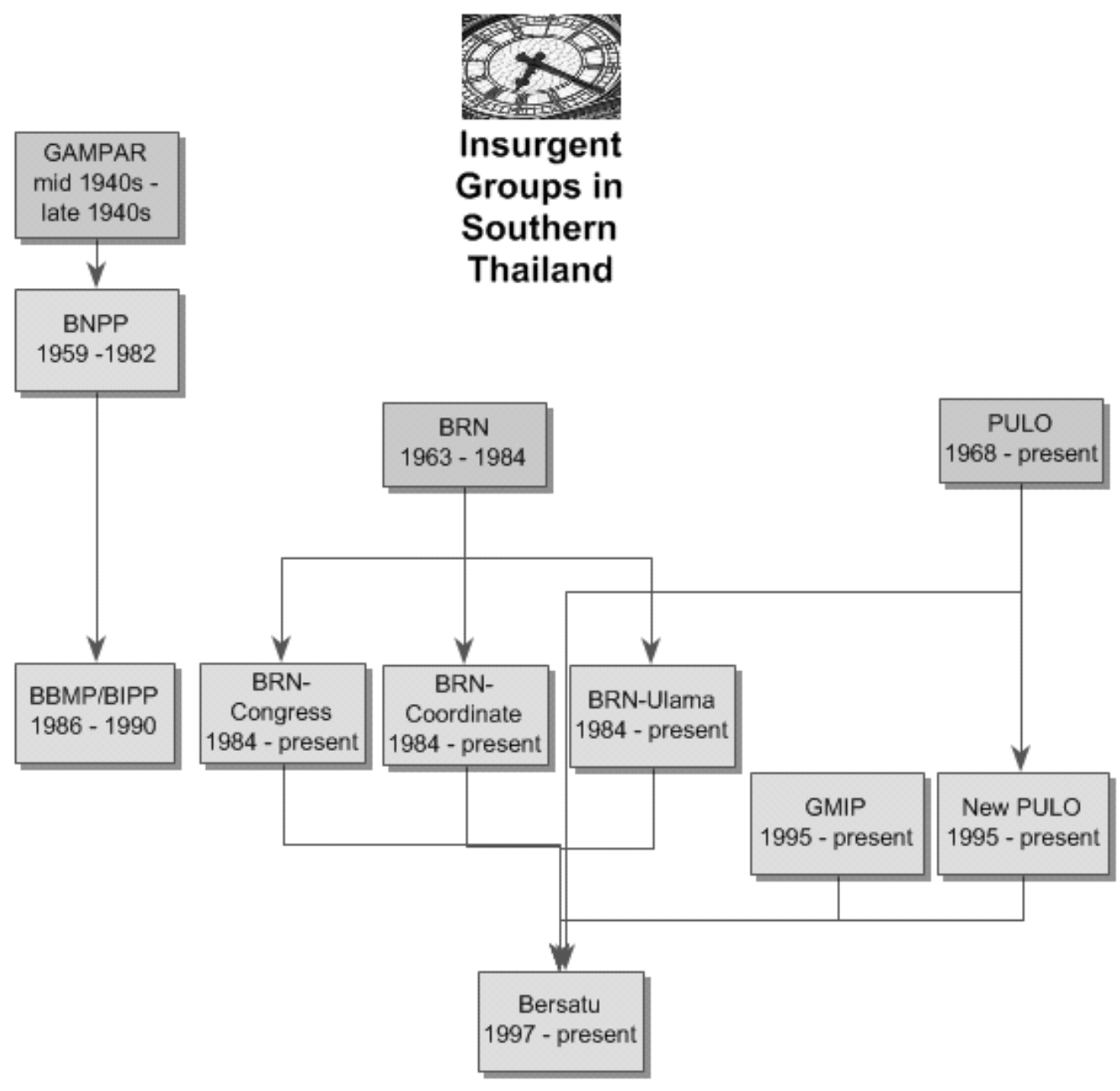

In the earls 1980s, BRN split up into three distinct factions: BRN-Congress, BRN-Ulama and BRN-Coordinate. While BRNCongress continued the military struggle and was perceived to be the most militant wing, BRN-Coordinate chose to undergo a fundamental change in strategy. Rather than keep fighting, the group chose to rebuild from scratch and opted for focusing on strengthening its numbers through youth work - a decision that would turn out to be of major importance for the group's success two decades later (Liow and Pathan, 2010:8-10). One reason for the re-structuring of these groups and the demise of the BNPP in the 1980s was a change in Thai policy.

Under the leadership of prime-minister Prem Tinsulanond, a dramatic change in policy towards the Deep South, known in Thai as tai rom yen (literally meaning "South in the cool shade") was made. Amnesties were granted to hundreds of separatist fighters, who could safely return to their villages without fear of persecution. Institutions like the Civilian-Police-Military Task Force (CPM-43) and the Southern Border Provinces Administration Centre (SBPAC) were established - the first aimed at providing better accountability regarding the police's actions and ensuring that extra-judicial killings were prosecuted, the latter a tool for political dialogue and a way for local MalayMuslim leaders to voice their grievances (McCargo, 2006:43). This "policy of attraction" proved extremely successful and the violence was reduced to a minimum from the mid-1980s to the late 1990s.

Despite this fact, other insurgent groups emerged in the meantime, such as the Gerakan Mujahideen Islam Patani (GMIP), a group led by Patani veterans from the war in Afghanistan, and an offshoot from PULO called New PULO. Additionally, in response to the dwindling of popular support in the mid-90s, an umbrella organisation was formed in 1997 that brought together all the organisations that were still active. This organisation was called Bersatu (meaning "United" in Malay) and managed to launch a military campaign, called "falling leaves" in the following year, which killed 146 Thai soldiers and left more than 80 wounded (Liow and Pathan, 2010:98n13; Abuza, 2009:27/28). The Thai state's response was swift and the leaders of many groups were arrested, making the operation a military success at an extremely high cost for Bersatu.

Before the re-escalation of violence in 2004, it had become quiet around the insurgency. Except for occasional violence, which then-prime minister Thaksin Shinawatra in an argumentation which is still prominent with many Thai simply attributed to criminal gangs, the violence seemed to have gone away (Jitpiromsri \& McCargo, 2010; Jones, 2007). While this success had been largely due to the policy of moderation and dialogue 
his predecessors has established, Thaksin upon taking office immediately shut down the SBPAC and the CPM-43, creating a time-bomb which went off in 2004 (McCargo, 2006). The new wave of insurgency, most likely spearheaded and dominated by the Barisan Revolusi Nasional-Coordinate faction of BRN, which had carefully and quietly rebuilt its structures, began and a vicious cycle of violence was started, when Thaksin opted for a harsh crackdown on southern Thailand's Malay-Muslims. This escalation reached its peak in the so-called Tak Bai massacre on 25 October 2004. On that day Thai police forces arrested hundreds of people protesting peacefully outside a police station against the arrest of Malay-Muslim village defence volunteers that had been robbed of their rifles by insurgents and were arrested by the police as suspected collaborators due to this. The police transported hundreds of the protesters to a detention centre some 130 kilometres away under inhumane conditions, causing death by dehydration and suffocation of 78 of the Malay-Muslims in custody (Pathmanand, 2006:75). Under Thaksin's term a momentum was created that provided the insurgency with further legitimacy, as the Thai state's perceived oppression and lack of respect for Malay-Muslims became highly visible, the consequences of which are felt to this day.

\section{Conclusion}

The insurgency, whose campaign of violence has been tormenting Thailand's Deep South since 2004, is not part of a global jihadist network and Patani is not a new front in the global war on terror. Instead, it is the most recent incarnation of a resistance and liberation movement that has been present for more than sixty years. Despite the Islamist rhetoric it is not primarily fuelled by religious fervour, but a desire to create acceptance for the distinct identity of southern Thailand's Malay-Muslims. Islam is only one of many rallying points around which this identity is constructed - historical narratives praising the Sultanate of Patani's "glorious past", condemnation of the oppressive Thai state and Malay ethnicity are just as important factors to be considered. Whether the insurgents' goal is a separate state or merely some form of local autonomy remains to be seen, but it appears to be clear that progress in Thailand's troubled South will only come if there is an acceptance by the Thai state of the Malay-Muslims' right to a distinct identity. Given the protracted nature of the conflict, the long history of reciprocal distrust and hatred and the connection to fundamental questions of identity, in order to make inroads for peace possible, the Thai government ought to rethink both its scepticism regarding the involvement of foreign actors such as NGOs and third party arbitration as well as its strategy in dealing with human rights abuses perpetrated by its security forces. The insurgents, on the other hand, should reconsider their strategy of not combining their violent struggle with any sort of negotiations. The fact that little is known about the insurgency's structure is due to a deliberate shift in strategy from classical guerrilla warfare to a more clandestine cell structure, making it impenetrable for Thai security forces and the secret service. Despite of this success in military terms, the continued violence has done little in terms of creating support or raising international awareness, while being extremely strenuous for the local population. The catch22 of southern Thailand's situation is that anyone coming out as a spokesperson for the insurgents will most likely face extreme repercussions by the Thai state, yet without this step there is little prospect for the situation to undergo significant change towards peace anytime soon. Given this clinch, only an increase in dialogue, tolerance and acceptance of differences paired with administrative reform appear to be a viable way for the Thai government to curtail the violence - economic programs, while certainly beneficial for a region that is about to inherit the top spot in the ranking of Thailand's poorest regions from the country's impoverished Northeast, might bring jobs, but will not bring peace. If these talks are politically impossible, a multi-track approach spearheaded by backchannel talks should be initiated in order to open channels for communication without the risk of losing face on the side of the Thai government or risking over-exposure on the side of the insurgent leaders. Only the actors themselves can take the steps towards peace and drive the process, but help from the outside should at least be considered in order to facilitate a meaningful dialogue - a model that has worked in Aceh.

\section{Bibliography}

Abuza, Z. (2009). Conspiracy of Silence: The Insurgency in Southern Thailand. Washington DC: United States Institute of Peace Press.

Aphornsuvan, T. (2004). Origins of Malay Muslim "Separatism" in Southern Thailand. Singapore.

Christie, C. J. (1998). A Modern History of Southeast Asia: Decolonization, Nationalism and Separatism. London, New York: I.B.Tauris.

Farouk, O. (1987). The Origins and Evolution of Malay-Muslim Ethnic Nationalism in Southern Thailand. In T. Abdullah $\&$ S. Siddique (Eds.), Islam and Society in Southeast Asia (pp. 250-281). Singapore: Institute of Southeast Asian Studies.

Grabowsky, V. (1995). Regions and National Integration in Thailand, 1892-1992. Wiesbaden: Harrassowitz.

Harish, S. P. (2006). Changing Conflict Indentities: The Case of the Southern Thailand Discord. Singapore.

Human Rights Watch. (2007). No One Is Safe.

International Crisis Group. (2005). Southern Thailand: Insurgency, Not Jihad. Asia Report N98.

International Crisis Group. (2009). Recruiting Militants in Southern Thailand. Asia Report $\mathrm{N}^{\circ} 170$.

Jerryson, M. K. (2010). Militarizing Buddhism: Violence in Southern Thailand. In M. K. Jerryson \& M. Juergensmeyer (Eds.), Buddhist Warfare (pp. 179-209). Oxford: Oxford University Press.

Jitpiromsri, S. (2010). Sixth Year of the Southern Fire: Dynamics of Insurgency and Formation of New Imagined Violence. Retrieved July 23, 2010, from www.deepsouthwatch.org/node/370. 
Jitpiromsri, S., \& McCargo, D. (2010). The Southern Thai Conflict Six Years On: Insurgency, Not Just Crime. Contemporary Southeast Asia, 32(2), 156-183.

Joll, C. M. (2010). Religion and Conflict in Southern Thailand: Beyond Rounding Up the Usual Suspects. Contemporary Southeast Asia, 32(2), 258-279.Jones.

S. A. (2007). Framing the Violence in Southern Thailand: Three Waves of Malay-Muslim Separatism. Thesis (Master of Arts) presented to the Center for International Studies of Ohio University.

Jory, P. (2007). From "Melayu Patani" to "Thai Muslim": The Spectre of Ethnic Identity in Southern Thailand. Asia Research Institute, Working Paper Series No. 84. Singapore.

Liow, J. C. (2009). Islam, Education and Reform in Southern Thailand: Tradition \& Transformation. Singapore: Institute of Southeast Asian Studies.

Liow, J. C., \& Pathan, D. (2010). Confronting Ghosts: Thailand's Shapeless Southern Insurgency. Lowy Institute for International Policy, Paper 20. Double Bay.

McCargo, D. (2006). Thaksin and the Resurgence of Violence in the Thai South: Network Monarchy Strikes Back? Critical Asian Studies, 38(1), 39-71.

McCargo, D. (2008). Tearing Apart the Land: Islam and Legitimacy in Southern Thailand. Ithaca, London: Cornell University Press.

McCargo, D., \& Jitpiromsri, S. (2008). A Ministry for the South: New Governance Proposals for Thailand's Southern Region. Contemporary Southeast Asia, 30(3), 402-428.

Melvin, N. J. (2007). Conflict in Southern Thailand - Islamism, Violence and the State in the Patani Insurgency. SIPRI Policy Paper No. 20, Stockholm.

Milner, A. (2010). The Malays. Oxford: Wiley-Blackwell.
Pathmanand, U. (2006). Thaksin's Achilles' Heel: The failure of Hawkish approaches in the Thai South. Critical Asian Studies, 38(1), 73-93.

Puaksom, D. (2008). Of a Lesser Brilliance: Patani Historiography in Contention. In M. J. Montesano \& P. Jory (Eds.), Thai South and Malay North: Ethnic Interactions on the Plural Peninsula (pp. 71-88). Singapore: National University of Singapore Press.

Reynolds, C. J. (2005). Nation and State in Histories of NationBuilding, with Special Reference to Thailand. In W. Gungwu (Ed.), Nation-Building: Five Southeast Asian Histories. Singapore: Institute of Southeast Asian Studies.

Reynolds, C. J. (2006). National Identity and Cultural Nationalism. In C. J. Reynolds (Ed.), Seditious Histories. Contesting Thai and Southeast Asian Pasts (pp. 245-275). Washington DC: University of Washington Press.

Samudavanija, C.-A. (2002). State-Identity Creation, State-Building and Civil Society, 1939-1989. National Identity and its Defenders: Thailand Today (pp. 49-70). Chiang Mai: Silkworm Books.

Sugunnasil, W. (2007). Islam, Radicalism, and Violence in Southern Thailand. In D. McCargo (Ed.), Rethinking Thailand's Southern Violence (pp. 112-136). Singapore: NUS Press.

Syukri, I. (1985). History of the Malay Kingdom of Patani: Sejarah Kerajaan Melayu Patani. Athens: Ohio University, Center for International Studies.

Walker, D. P. (2005). Conflict Between the Thai and Islamic Cultures in Southern Thailand (Patani) 1948-2005. Islamiyyat, 27(1), 81 - 117.

Wang, G. (2005). Nation-building: Five Southeast Asian Histories. Singapore: Institute of Southeast Asian Studies.

Yusuf, I. (2007). Faces of Islam in Southern Thailand. East West Center, Working Paper Series $N^{\circ} 7$, Washington DC.

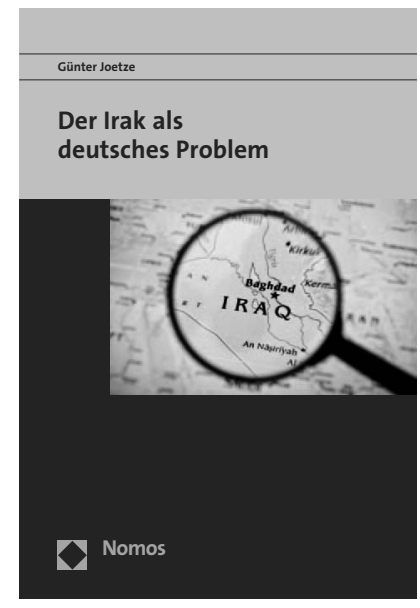

\section{Der Irak als deutsches Problem \\ Von Günter Joetze \\ 2010, 310 S., brosch., 29,- $€$, ISBN 978-3-8329-5365-2}

Der Irak-Krieg und der deutsche Widerspruch hielten unsere Öffentlichkeit ein Jahr lang in Bann. Noch nie war die Bundesrepublik solchen Polemiken ihres Hauptverbündeten ausgesetzt. Auch sie trägt noch heute an den Folgen für die internationale Ordnung. Um diesen Problemen nachzugehen, sichtete Dr. Günter Joetze seit 2002 amtliches Material und befragte Zeitzeugen. 